\title{
Chemical Composition of the Essential Oils in Eugenia caryophylata, Thunb from Amboina Island
}

\author{
Hanoch Julianus Sohilait \\ Department of Chemistry, Faculty of Mathematic and Natural Science, Pattimura University, Ambon, Indonesia
}

Email address:

nokesohilait@yahoo.com

To cite this article:

Hanoch Julianus Sohilait. Chemical Composition of the Essential Oils in Eugenia caryophylata, Thunb from Amboina Island. Science Journal of Chemistry. Vol. 3, No. 6, 2015, pp. 95-99. doi: 10.11648/j.sjc.20150306.13

\begin{abstract}
The essentials oils in Eugenia caryophylata, Thunb from Amboina Island on the bud, leaf and stem by steam distillation were isolated. Result of isolation was analyzed by GC and GC-MS. Five component were identified in the bud, leaf and stem oil. Main chemical component in the bud oil are eugenol (81.13-84.44 \%), eugenyl acetate (11.60-15.02\%) and $\beta$ caryophyllene (3.45-4.60\%) respectively and eugenol (81.06-86.04\%), $\beta$-caryophyllene (11.95-16.16\%), eugenyl acetate $(2.02-3.05 \%)$ in leaf oil, while in stem oil eugenol (97.20-98.83\%).
\end{abstract}

Keywords: Eugenia caryophylata, Essential Oils, Chemical Composition, Amboina Island

\section{Introduction}

The clove tree, Eugenia caryophylata, Thunb (=Syzigium aromaticum, L.), (Myrtaceae), grown naturally in Moluccas Islands, East Indonesia, and were cultivated in Tanzania, Madagascar, Sri Langka, India, Malaysia, Brazil, Jamaica and Guinea [1]. Local name of these trees from Moluccas Islands is cengkeh; the trunk of tree can grow as height as 812 meters, on altitudes of 10.0-1400.0 m above the sea level in Amboina Island. Clove can be used in cooking, either whole or in ground form. The spice is used in Europa and Asia, and in Indonesia its use for cigarettes, that is well known as "kreteks" [2]. Furthermore, the essential oil of clove has been widely use as spice and is well known for its medicinal properties. It is active against oral bacteria associated and fungi [3]. Previous studies also have reported antifungal [4-6], antioxidant [7-9], antibacterial [10,13], and anti-inflammatory $[1,13]$ properties of clove oil. Main component of clove oil, eugenol, has been used as an anticancer [14-15], and as starting material for synthesis analog L- $\alpha$-metil DOPA [16]. Research studies [2, 18-20] of clove essential oil from different parts of the world showed that the major component of the clove oil is usually eugenol, $\beta$ caryophyllene, $\alpha$-humulene, caryophyllene oxide and eugenyl acetate respectively, although different in concentration. A comparison of the published results reveals a great variability in chemical compositions of the clove essential oils. Eighteen components were identified in essential oil from Turkey clove bud, where major components are eugenol (87\%), eugenyl acetate $(8.01 \%)$ and $\beta$-caryophyllene $(3.56 \%)$, [2]. There are ten components in clove essential oil, with the main components are eugenol (77.81\%), eugenyl acetate $(21.30 \%)$ and $\beta$-caryophyllene (8.44\%) [17]. Thirty-eight components were identified in the clove leaf oil from Bangladesh, and the main components are eugenol (74.30\%), eucalyptol $(5.80 \%), \alpha$-cadinol $(2.43 \%)$. Thirty one components in bud oil were identified and the main components are eugenol (47.70\%), $\beta$-caryophyllene (18.90\%), benzdene-1-ethyl-3-nitro (11.10\%) and benzoic acid 3-(1-methylethyl) (8.90\%) [18]. Other work that was carried out on the bud and leaf essential oil of clove from India and Madagascar were found 28 and 35 components respectively from the bud oils and the leaf oil from Madagascar is 22 components. Major components in the bud oil from India are eugenol (70 \%) followed by $\beta$ caryophyllene (19.5\%) and eugenyl acetate (2.1\%). A comparison components of bud and leaf oils from Madagascar is $82.6 \%: 82.0 \%$ for eugenol, $7.2 \%: 13.0 \%$ for $\beta$-caryophyllene, and $6.0 \%: 0.4 \%$ for eugenyl acetate [19]. The research studies to compare of Madagascar, Indonesia and Zanzibar bud, leaf and stem essential oils have found 10 component. Major component in the bud essential oil from Madagascar and Indonesia are eugenol $(72.08-80.31 \%$ and $77.32-82.36 \%), \beta$-caryophyllene $(2.36-6.38 \%$ and 5.34 $8.64 \%)$ and eugenyl acetate $(11.68-21.32 \%$ and 8.61 $10.55 \%$ ). Major components in the leaf essential oil from Madagascar and Indonesia are eugenol $(80.87-83.35 \%$ vs 
75.04 - 77.54\%), $\beta$-caryophyllene (11.65 - $15.02 \%$ vs 17.04 $19.53 \%)$ and eugenyl acetate $(0.29-1.45 \%$ vs $0-0.06 \%)$. Major component oil of Madagascar, Indonesia and Zanzibar stem essential oils are eugenol (91.81 - 96.65\%, 88.76 $89.28 \%$ and $87.52-89.47 \%$ ), $\beta$-caryophyllene (1.66 - 4.48\%, $7.40-7.75 \%$ and $7.19-9.70 \%$ ), [20]. This paper reports results of chemical composition of clove bud, leaf and stem oils obtained from original trees grown in Amboina Island. So far, no study has been done on the chemical composition of clove in Amboina Island.

\section{Materials and Methods}

\subsection{Material}

Bud, leaf and stem plant of clove were collected from different locations in northern, southern, eastern and western parts of Amboina Island, Moluccas. Bud (4 samples), Leaf (4 samples) and Stem (12 samples) were deposited in the Organic Chemistry Laboratory, Pattimura University, Ambon. Raw material was dried on the sun for five until seven days.

\subsection{Isolation of Essential Oil from Bud, Leaf and Stem of Eugenia Caryophylata}

The dry plant materials $(2.0 \mathrm{~kg})$ of bud, leaf $(1.6 \mathrm{~kg}$.) and stem $(1.2 \mathrm{~kg})$ of Eugenia caryophylata (Figure 1) were obtained by steam-distillation method by conventional steam distiller, for 6 hours. The essential oil samples were dried by anhydrous sodium sulfate $\left(\mathrm{Na}_{2} \mathrm{SO}_{4}\right)$ and stored in cool and brown bottle until analysis conducted.

\subsection{Gas Chromatographs (GC)}

GC analysis of clove essential oil was performed on a Shimadzu QP-2010, equipped with a FID and Rtx-5 using a fused silica capillary column $(30 \mathrm{~m} \times 0.25 \mathrm{~mm}$ ID, film thickness $1.0 \mu \mathrm{m}$ ). Oven temperature was from $70{ }^{0} \mathrm{C}$ for 5 minutes and programmed heating from 70 to $220{ }^{\circ} \mathrm{C}$ at a rate of $10^{\circ} \mathrm{C}$ for 6 minutes, and from $280{ }^{\circ} \mathrm{C}$ for 5 minutes, injector temperature $270{ }^{\circ} \mathrm{C}$; detector temperature $280{ }^{\circ} \mathrm{C}$; pressure of carrier nitrogen gas at inlet 7 psi, split 100 and volume was $0.2 \mu \mathrm{L}$.

\subsection{Gas Chromatography-Mass Spectrometry (GC-MS)}

GC-MS analyses of clove essential oil were performed using Shimadzu QP-2010 Plus at $70 \mathrm{eV}$ and $320{ }^{\circ} \mathrm{C}$ with auto sampler, system equipped with Rtx-5 fused silica capillary column (30 m x $0.25 \mathrm{~mm}$ ID, film thickness $1.0 \mu \mathrm{m})$. Oven temperature was from $70{ }^{0} \mathrm{C}$ for 5 minutes, than programmed heating from 70 to $220{ }^{\circ} \mathrm{C}$ at a rate of $10{ }^{\circ} \mathrm{C}$ for 6 minutes, and from $280{ }^{0} \mathrm{C}$ for $5 \mathrm{~min}$, injector temperature $270{ }^{\circ} \mathrm{C}$. $100 \%$ pure helium gas was used as a carrier gas at the constant flow rate $2.30 \mathrm{~mL} / \mathrm{min}$, split ratio 100 , ion source temperature $225{ }^{0} \mathrm{C}$. The spectrum of the unknown component was compared with the spectrum of known components stored in the Wiley 7 library. Name, molecular weight and structure of the component of the test materials were ascertained.

\section{Results and Discussion}

\subsection{Performance of Bud, Leaf and Stem Essential Oil of Clove}

The essential oils of bud, leaf and stem were distilled from dry plant material on equipment of the steam distillation (Figure 2). Average yields of bud, leaf and stem essential oils were calculated toward dry material. The results of clove oil from steam-distillation revealed that from bud have yield $(7.05 \% \mathrm{w} / \mathrm{w})$, leaf $(3.21 \%, \mathrm{w} / \mathrm{w})$ and stem $(3.58 \%, \mathrm{w} / \mathrm{w})$.

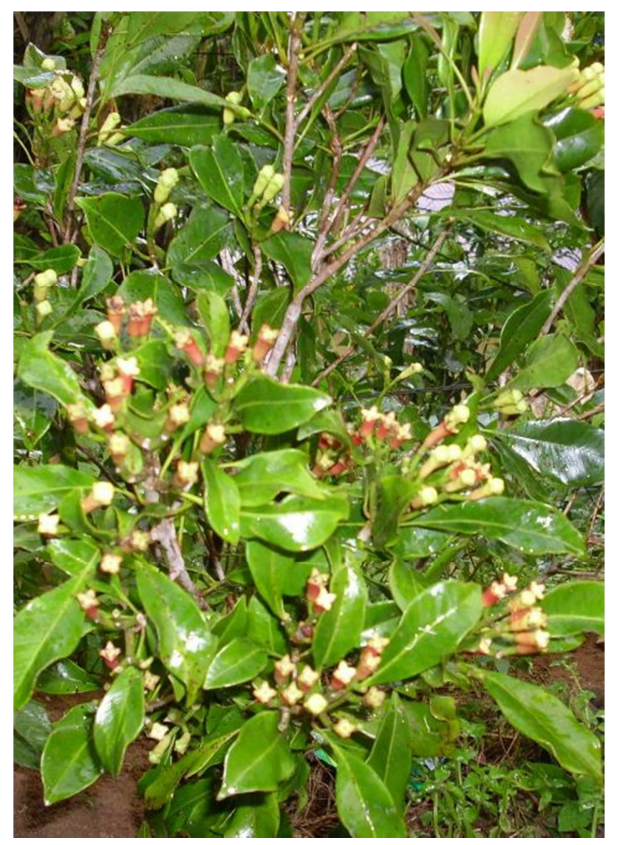

Figure 1. Eugenia caryophylata, Thunb.

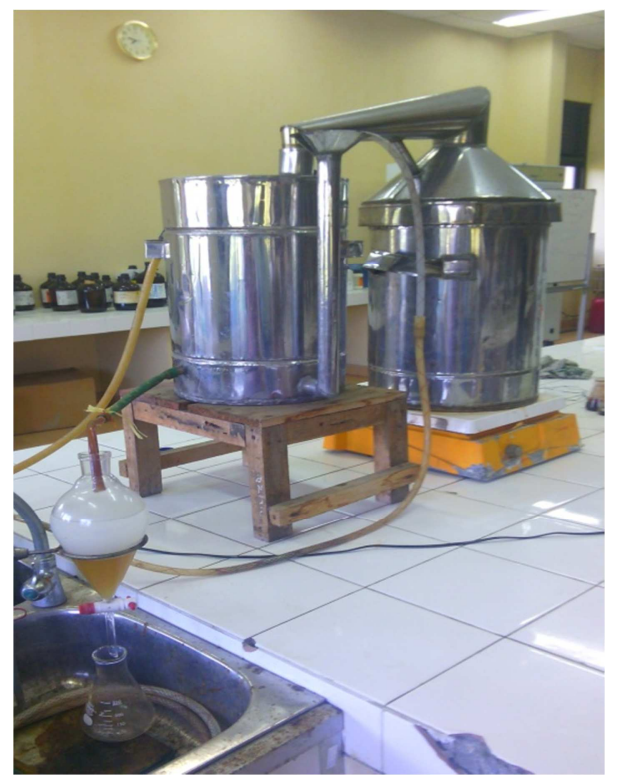

Figure 2. Conventional steam-distillation. 


\subsection{Chemical Composition of Bud, Leaf and Stem Clove Essential Oils from Amboina Island}

The clove of bud essential oil (4 samples), leaf essential oil (4 samples) and stem essential oil (12 samples) of Eugenia caryophylata, Thunb were analyzed by GC and GC-MS. Five components were identified and quantified, as shown in Table 1, according to their elution order on the Rtx-5 column. Components were presented from the lowest to the highest concentration. The major components of bud, leaf and stem oil are eugenol $(81.13-84.44 \%, 81.06-86.04 \%$ and $97.20-$ $98.83 \%), \beta$ - caryophylene $(3.45-4.60 \%, 11.95-16.16 \%)$ and $0.49-1.73 \%)$ and eugenyl acetate (11.60 - 15.02\%, 2.02 - $3.05 \%$ and $0.68-0.73 \%$ ). Three major components were observed by GC-MS analysis for ion chromatogram in bud, leaf and stem clove oils. In comparison to standard library data, the peak at $\mathrm{m} / \mathrm{z} 164\left(\mathrm{M}^{+}\right), \mathrm{C}_{10} \mathrm{H}_{12} \mathrm{O}_{2}$, was identified as eugenol (Figure $3 \mathrm{~A}$ ), the peak at $\mathrm{m} / \mathrm{z} 204\left(\mathrm{M}^{+}\right), \mathrm{C}_{15} \mathrm{H}_{24}$, was identified as $\beta$-caryophylene (Figure $3 \mathrm{~B}$ ) and the peak at $\mathrm{m} / \mathrm{z}$ $206\left(\mathrm{M}^{+}\right), \mathrm{C}_{12} \mathrm{H}_{14} \mathrm{O}_{3}$, was identified as eugenyl acetate (Figure $3 \mathrm{C}$ ). The are two minor components in the mass spectrum, the peak at $\mathrm{m} / \mathrm{z} 204\left(\mathrm{M}^{+}\right), \mathrm{C}_{15} \mathrm{H}_{24}$, was identified as humulene and the peak at $\mathrm{m} / \mathrm{z} 177\left(\mathrm{M}^{+}\right.$- $\mathrm{CH}_{3} \mathrm{CO}$.] was identified as caryophylene oxide.

Based on this result, it can be inferred that oil from stem contain higher eugenol content than bud and leaf oil, but lower $\beta$-caryophylene and eugenyl acetate content than on bud and leaf oil from Amboina Island. Moreover oil from leaf contains higher $\beta$-caryophylene content than bud and stem, and oil from bud contain higher in eugenyl acetate content than oil from leaf and stem.

A typical gas chromatogram of Amboina Island clove oil is shown in Figure 4 (oil from bud), Figure 5 (oil from leaf) and Figure 6 (oil from stem).

This study reveals that the clove essential oils compounds from Amboina Island (bud, leaf and stem) have differences when compared to the earlier reports [1-2, 17-20]. The highest concentration of eugenol on stem oil makes it potentially use as medicines because it exhibit antibacterial, antifungal, anti-inflammatory activity, anticancer and antioxidant properties [1, 3-15].

Table 1. Chemical composition of bud, leaf and stem clove essential oils from Amboina Island.

\begin{tabular}{|c|c|c|c|c|c|}
\hline Compoud Name & M.W & Formula & Bud (\%) & Leaf $(\%)$ & Stem $(\%)$ \\
\hline Eugenol & 164 & $\mathrm{C}_{10} \mathrm{H}_{12} \mathrm{O}_{2}$ & $81.13-84.44$ & $81.06-86.04$ & $97.20-98.83$ \\
\hline$\beta$-caryophylene & 204 & $\mathrm{C}_{15} \mathrm{H}_{24}$ & $3.45-4.60$ & $11.95-16.16$ & $0.49-1.73$ \\
\hline Humulene & 204 & $\mathrm{C}_{15} \mathrm{H}_{24}$ & $0.38-0.50$ & $1.22-1.80$ & $0.00-0.30$ \\
\hline Eugenyl acetate & 206 & $\mathrm{C}_{12} \mathrm{H}_{14} \mathrm{O}_{3}$ & $11.60-15.02$ & $2.02-3.05$ & $0.68-0.73$ \\
\hline Caryophylene oxide & 220 & $\mathrm{C}_{15} \mathrm{H}_{24} \mathrm{O}$ & $0.05-0.24$ & $0.00-0.37$ & $0.00-0.89$ \\
\hline
\end{tabular}

(A)

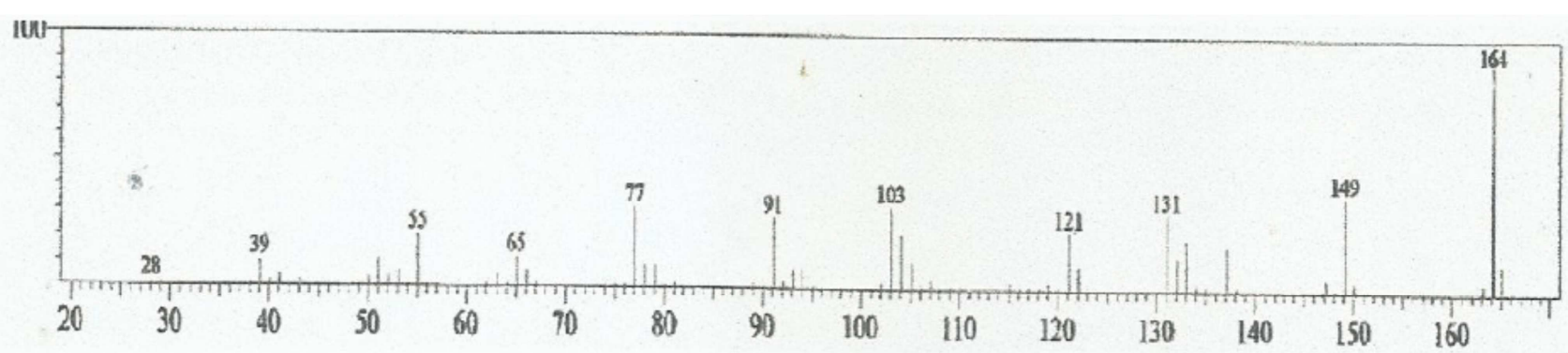

(B)

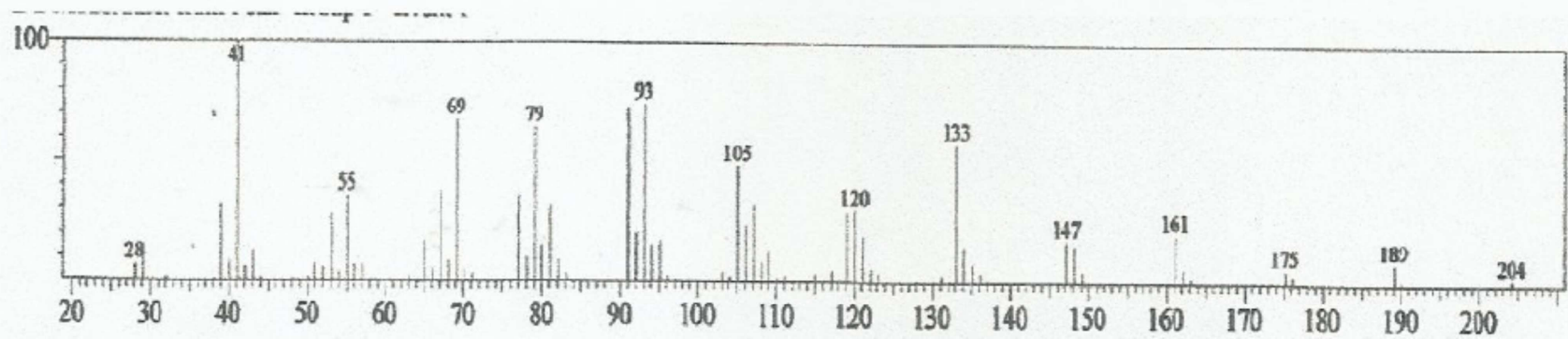

(C)

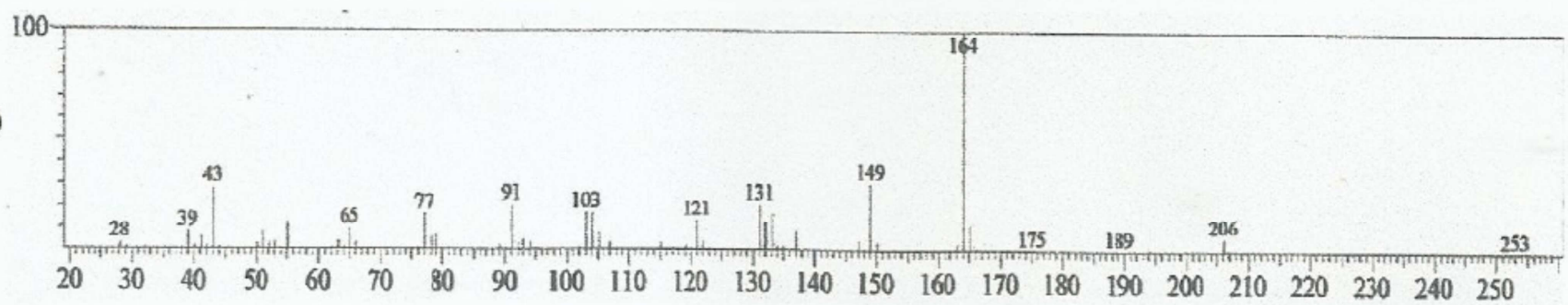

Figure 3. Mass spectrum of three major component in clove oil, eugenol (A), $\beta$-caryophylene (B), eugenyl acetate (C). 


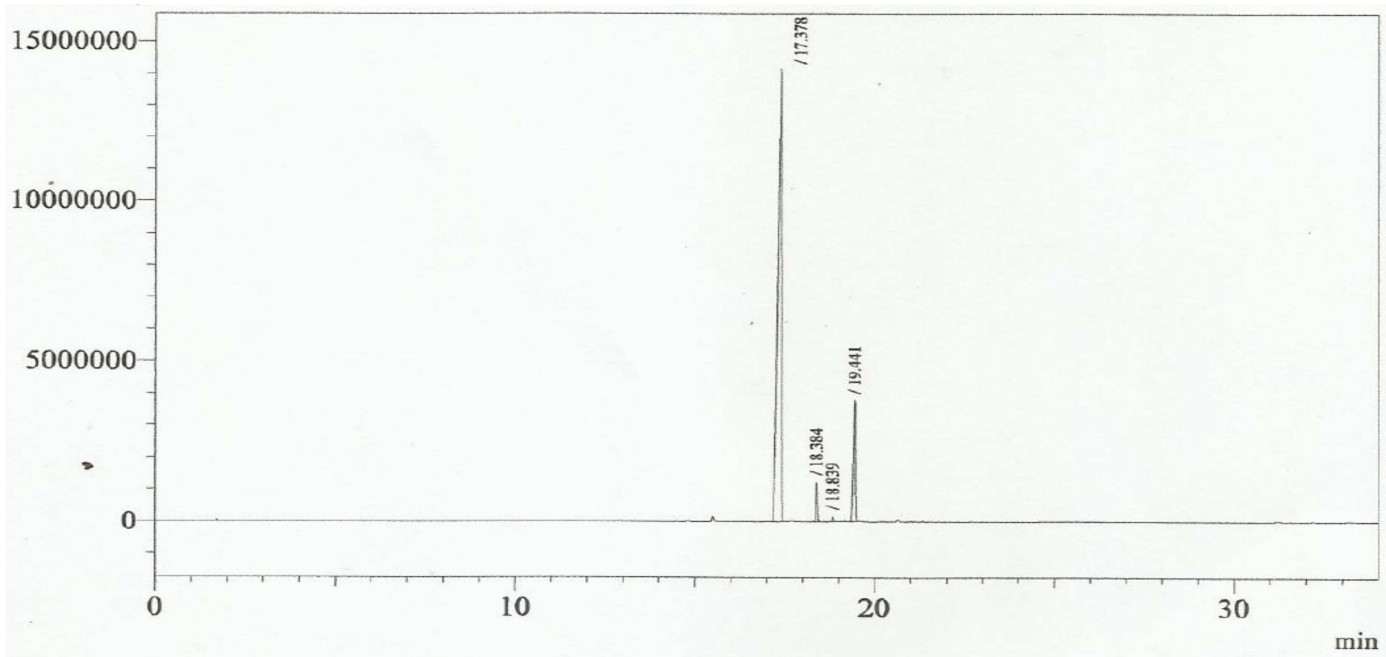

Figure 4. A typical gas chromatogram of the essential oil from Amboina Island bud oils.

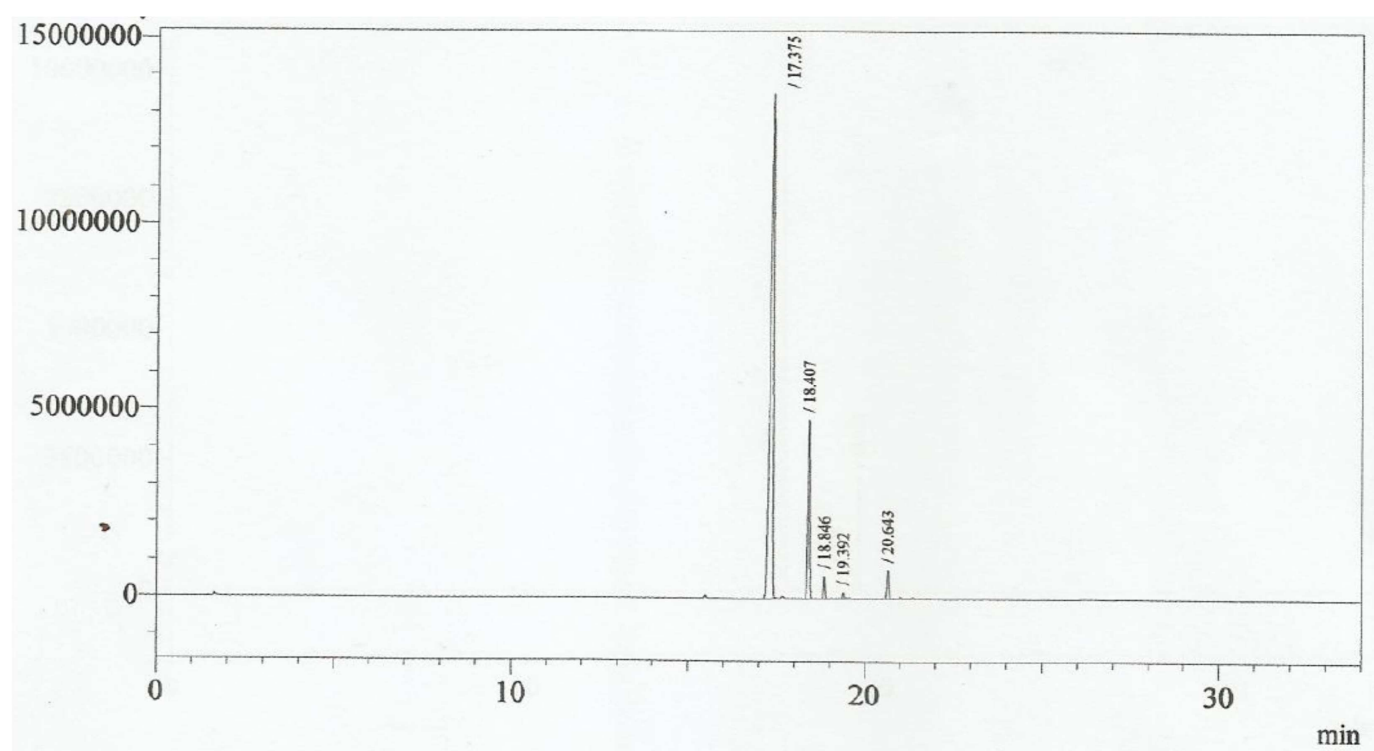

Figure 5. A typical gas chromatogram of the essential oil from Amboina Island leaf oils.

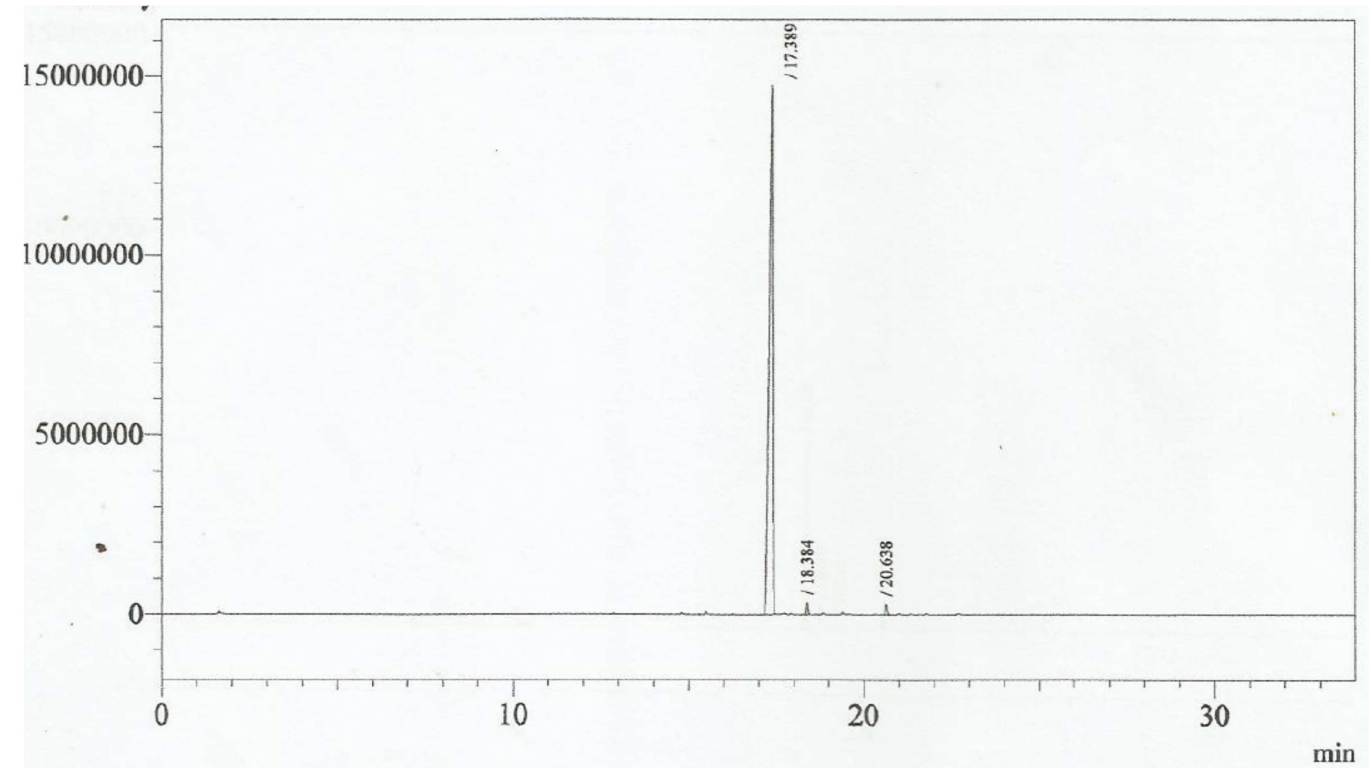

Figure 6. A typical gas chromatogram of the essential oil from Amboina Island stem oils. 


\section{Conclusions}

The chemical composition of essential oils from clove (Eugenia caryophylata) provided from Amboina Island was investigated. Essential oil from bud, leaf and stem clove oil, was obtained from steam distillation method, and its chemical composition was determined by GC and GC-MS. The result indicated that the essential oils mainly had about $81.13-84.44 \%$ eugenol, $11.60-15.02 \%$ eugenyl acetate and $3.45-4.60 \% \beta$-caryophyllene in the oil from bud, 81.06 - $86.04 \%$ eugenol, $11.95-16.16 \% \beta$-caryophyllene and 2.02 - $3.05 \%$ eugenyl acetate in oil from leaf, $97.20-98.83 \%$ eugenol in oil from stem, thus only one main component.

\section{Acknowledgement}

The author thanks the Department of Chemistry, FMIPA, Pattimura University, Ambon for providing the necessary infrastructure and financial support to carry out this work.

\section{References}

[1] Ozturk A, Ozbek H, The Anti-inflammatory activity of Eugenia caryophyllata essential oil: An animal model of antiinflammatory activity, Eur. J. Gen. Med., 2005, 2 (4), 159163.

[2] Alma H. K, Ertas M, Nitz $\mathrm{S}$ and Kollmannsberger $\mathrm{H}$, Chemical composition and content of essential oil from the bud of cultivated Turkish clove (Syzigium aromaticum L.), BioResources, 2007, 2 (2), 265-269.

[3] Pundir R. K, Jain Pr and Sharma Ch, Antimicrobial activity of ethanolic extracts of Syzigium aromaticum and Allium sativum Against food associated bacteria and fungi, Ethnobotanical Leaflets., 2010, 14, 344-360.

[4] Park M. J, Gwak K. S, Yang I, Choi W. S, Jo H. J, Chang J. W, Jeung E. B, and Choi I. G, Antifungal activities of the essential oils in Syzigium aromaticum (L.) Merr. Et Perry and Leptospermum patersoii Bailey and their constituents against various dermatophytes, J. Microbio., 2007, 45 (5), 460-465.

[5] Humini K. N, Hamdane R, Boutoutaou R, Kihal M and Henni J. E, Antifungal activity of clove (Syzigium aromaticum L) essential oil against phytopathogenic fungi of tomato (Solanum lycopersicum L.) in Algeria, J. Exp. Bio. and Agric. Sci., 2014, 2 (5), 447-454.

[6] Yazdanpanah L and Mohamadi N, Antifungal activity of the clove essential oil Syzigium aromaticum on Paecilomyces variotii agent of pistachio dieback, J. Bio. \& Env. Sci., 2014, 4 (6), 42-45.

[7] Jirovetz L, Buchbauer G, Stoilova I, Stoyanova A and Schmidt E, Chemical composition and antioxidant properties of clove leaf essential oil, J. Agric. Food chem., 2006, 54, 6303-6307.
[8] Nassar M. I, Gaara A. H, El-Ghorab A. H, Farrag A. R. H, Shen H, Huq E and Mabry T. J, Chemical constituents of clove (Syzigium aromaticum), Fam. Myrtaceae and their antioxidant activity, Rev. Latinoamer. Quim., 2007, 35 (3) ,4757.

[9] Abozid M. M and El-Sayed S. M, Antioxidant and protective effect of clove extracts and clove essential oil on hydrogen peroxide treated rats, Int. J. chem. Tech. Res., 2013, 5 (4), 1477-1485.

[10] Saeed M, Nadeem M, Khan M. R, Shabbir M. A, Shehzad A and Amir A. M, Antimicrobial activity of Syzigium aromaticum extracts against food spoilage bacteria, Glob. J. Med. Microbiol. Rev., 2013, 1 (1), 27-35.

[11] Cortes-Rojas D. F, Ferandes de Souza, C. R, Pereira Olivera $\mathrm{W}$, Clove (Syzigium aromaticum): A Precious spice, Asian Pac. J. Trop. biomed., 2014, 4 (2), 90-96.

[12] Chaieb K, Hajlaoui H, Zmantar T, Kahla-Nakbi A. B, Rouambhia M, Mahdouani K and Bakhroul A, The chemical composition and biological Activity of clove essential oil, Eugenia caryophyllata (Syzigium aromaticum L. Myrtaceae): A short review, Phytother. Res., 2007, 21, 501-506.

[13] Kamatou G. P, Vermaak I and Viljoen A. M, Eugenol- From the remote Maluku Islands to the international market place: A review of a remarkable and versatile molecule, Molecules, 2012, 17, 6953-6981.

[14] Wei Ch. Ch, Meen W. H, Hsi Ch. W, Yin Y. Ch, Yao Ch. H, and Je Ch., The analysis of eugenol from the essential oil of Eugenia caryophyllata by HPLC and against the proliferation of cervical cancer cells, J. Med. Plant. Res., 2011, 5 (7), 11211127.

[15] Vidhya N and Devaray S. N, Induction of apoptosis by eugenol in human breast cancer cells, Indian J. Exp. Bio., 2011, 49, 871-878.

[16] Sohilait H. J, Sastrohamidjojo H, Sabirin M and Gossert J. S, Synthesis of analog L- $\alpha$-methyl DOPA from eugenol, Indo. J. Chem., 2005, 5 (3), 198-2002.

[17] Gupta M, Singh D, Gularia P and Gupta S, GCMS analysis and identifications of chemical constituents of Syzigium aromaticum, Brassica compestris and cow ghee, J. Chem. Pharm. Res., 2015, 7 (1), 568-572.

[18] Bhuiyan Md. N. I, Begum J, Nandi N. Ch and Akter F, Constituents of the essential oil from leaves and buds of clove (Syzigium aromaticum, L. Alston), Afr. J. Plant Sci., 20104 (11), 451-454.

[19] Srivastava A. K, Srivastava S. K and Syamsudar K. V, Bud and leaf essential oil composition of Syzygium aromaticum from India and Madagascar, Flavour Fragr. J., 2005, 20, 5153.

[20] Razafimamonjison G, Jahiel M, Duclos Th, Ramanoelia P, Fawbush F, Danthu P, Bud, leaf and stem essential oil composition of Syzigium aromaticum from Madagascar, Indonesia and Zanzibar, Int. J. Basic Appl. Sci., 2014, 3 (3), 224-233. 